\title{
Mortality Among Hardmetal Production Workers
}

\section{Citation for published version:}

McElvenny, DM, MacCalman, L, Sleeuwenhoek, AJ, Davis, A, Miller, BG, Alexander, C, Cowie, H, Cherrie, JW, Kennedy, KJ, Esmen, NA, Zimmerman, SD, Buchanich, JM \& Marsh, GM 2017, 'Mortality Among Hardmetal Production Workers: UK Cohort and Nested Case-Control Studies', Journal of Occupational and Environmental Medicine, vol. 59, no. 12, pp. e275-e281. https://doi.org/10.1097/JOM.0000000000001036

\section{Digital Object Identifier (DOI): \\ 10.1097/JOM.0000000000001036}

\section{Link:}

Link to publication record in Heriot-Watt Research Portal

\section{Document Version:}

Peer reviewed version

\section{Published In:}

Journal of Occupational and Environmental Medicine

\section{Publisher Rights Statement:}

This is the accepted version of the following article: McElvenny, D., MacCalman, L., Sleeuwenhoek, A., Davis, A., Miller, B., Alexander, C., Cowie, H., Cherrie, J., Kennedy, K., Esmen, N., Zimmerman, S., Buchanich, J. and Marsh, G. (2017). Mortality Among Hardmetal Production Workers., which has been published in final form at https://doi.org/10.1097/JOM.0000000000001036

\section{General rights}

Copyright for the publications made accessible via Heriot-Watt Research Portal is retained by the author(s) and / or other copyright owners and it is a condition of accessing these publications that users recognise and abide by the legal requirements associated with these rights.

\section{Take down policy}

Heriot-Watt University has made every reasonable effort to ensure that the content in Heriot-Watt Research Portal complies with UK legislation. If you believe that the public display of this file breaches copyright please contact open.access@hw.ac.uk providing details, and we will remove access to the work immediately and investigate your claim. 


\section{Mortality among Hard Metal Production Workers: UK Cohort and Nested Case-Control Studies}

Damien M. McElvenny ${ }^{1 \mathrm{a}} \mathrm{PhD}$, Laura A. MacCalman ${ }^{1} \mathrm{PhD}$, Anne Sleeuwenhoek ${ }^{1} \mathrm{PhD}$, Alice Davis ${ }^{1} \mathrm{BSc}$, Brian G. Miller ${ }^{1} \mathrm{PhD}$, Carla Alexander ${ }^{1} \mathrm{MSc}$, Hilary Cowie ${ }^{1} \mathrm{BSc}$, John W. Cherrie ${ }^{1,2} \mathrm{PhD}$, Kathleen J. Kennedy ${ }^{3}$ PhD, Nurtan A. Esmen ${ }^{3}$ PhD, Sarah D. Zimmerman ${ }^{4}$ MS, Jeanine M. Buchanich ${ }^{4}$ PhD Gary M. Marsh ${ }^{4} \mathrm{PhD}$.

${ }^{1}$ Institute of Occupational Medicine, Edinburgh, EH14 4AP, UK

${ }^{2}$ Heriot Watt University, Institute of Biological Chemistry, Biophysics and Bioengineering, Edinburgh, EH14 4AS, UK

${ }^{3}$ Division of Environmental and Occupational Health Sciences, School of Public Health, University of Illinois at Chicago, Chicago, IL 60612, USA

${ }^{4}$ Center for Occupational Biostatistics and Epidemiology, Department of Biostatistics, Graduate School of Public Health, University of Pittsburgh, Pittsburgh, PA 15261, USA

${ }^{a}$ Address for correspondence:

Professor Damien McElvenny

Institute of Occupational Medicine

Research Avenue North

Riccarton

Edinburgh EH14 4AP

United Kingdom

Tel. +44 (0)1314498085

Fax. $+44(0) 1314498084$

Email. Damien.McElvenny@iom-world.org

Funding: International Tungsten Industry Association via a subcontract from the University of Pittsburgh.

Conflicts of Interest: None declared. 
Short title: Lung cancer mortality in UK hard metal workers

Manuscript Word count: 4,107

Abstract Word count: 133 


\section{ABSTRACT}

\section{Objective}

To characterise the mortality at two hardmetal production factories in the United Kingdom as part of an international study.

\section{Methods}

SMRs were calculated based on mortality rates for England and Wales, and local rates. A nested case-control study of lung cancer was undertaken.

\section{Results}

The cohort comprised 1,535 workers, with tracing complete for $94.4 \%$. All-cause mortality was statistically significantly low for all cancers and non-malignant respiratory disease, and for lung cancer was non-significantly low. The SMR for lung cancer for maintenance workers was elevated, base $d$ onl only six deaths. The odds ratio for lung cancer per year of exposure to hardmetal was $0.93(0.76-1.13)$.

\section{Conclusions}

In this small study there is no evidence to support that working in the UK hard-metal manufacturing industry increased mortality from any cause including lung cancer.

Keywords: Cohort, Nested case-control; Lung cancer; Hardmetal, Cobalt, Tungsten carbide 


\section{INTRODUCTION}

Hardmetals are materials in which metallic carbides are bound together by a soft and ductile metal, often cobalt. The cobalt metal binder is obtained as a very fine powder and is blended with carbide powders in ball mills, vibratory mills or grinding machines using carbide balls. The mills are lined with carbide, low-carbon steel or stainless-steel sleeves. Intensive milling is necessary to break up the initial carbide crystallites and disperse the cobalt among the carbide particles to enhance wetting by cobalt during sintering. Milling is performed under an organic liquid such as alcohol, hexane, heptane or acetone; in the process, a solid lubricant such as paraffin wax or polyethylene glycol is added to the powder blend to strengthen the pressed or consolidated powder mix. After milling, the organic liquid is removed by drying. In a spray-drying process, commonly used in the hardmetal industry, a hot inert gas such as nitrogen impinges on a stream of carbide particles to produce free-flowing spherical powder aggregates. The milled and dried grade powders are pressed to desired shapes in hydraulic or mechanical presses. Special shapes may require a pre-sintering operation followed by machining or grinding to the final form. Cold isostatic pressing, followed by forming the powder into the desired shape, is also common in the manufacture of wear-resistant components and metal-forming tools. Rods and wires are formed by an extrusion process ${ }^{(1)}$.

It has been suggested that exposure to hardmetal, tungsten carbide with a cobalt binder, may increase the risk of lung cancer amongst workers ${ }^{(2-5)}$. A study of lung cancer has been undertaken in manufacturing plants in the United States, Germany, Sweden, Austria and the UK ${ }^{(6)}$; this study reports on the findings of the UK component of the study, focusing on two hardmetal manufacturing sites in the West Midlands in England. The University of Pittsburgh coordinated the overall study under the leadership of Professor Gary Marsh. The exposure assessment component of the study was carried out by the University of Illinois at Chicago under the leadership of Professor Nurtan Esmen. 


\section{METHODS}

\section{Study Clearances}

The extensive research governance clearances required for this study are set out in an Appendix.

\section{Cohort enumeration and data collection process}

Data for current and recent workers were obtained from an electronic download from the company's human resources department computer system. This was supplemented by a download of identifiers of current workers from the company's payroll system and a download of former workers currently drawing a pension from the company's occupational pension scheme.

Following visits to the factory and discussion with senior management and human resources staff, historic human resources files were identified in two locations on the company's premises, one of which was their UK head office where no hardmetal manufacturing took place. These records were scanned as PDF files by a specialist scanning company local to where the records were held. The scanning company was also party to the Data Sharing Agreement with the hardmetal manufacturing company.

At IOM, data were extracted from the scanned PDFs before being merged with the data obtained electronically. Data extraction was validated by cross-checking results against a random sample of PDFs. Any close, but not exact, matches were resolved by visual inspection of the data from different sources.

Standard checks of cohort completeness, combined with knowledge of when production began at both factories, suggested that records were not retained for early employees at either factory. Hence a decision was taken to commence follow-up from 1980.

\section{History of Production at the UK Factories}


Manufacture of hardmetal tips from imported powders in Factory A started in 1931. However, it was only possible to go back to roughly 1970 for this history. From the 1970s until 2010 there were two Plants, one where ready to press powder (RTP) was prepared and the other where metal products were produced, using RTP from the first Plant. During 2010 metal products processes were moved to the RTP Plant. Tungsten carbide powder is mixed with other materials to produce different grades of RTP powder. The powder is then pressed and sintered to produce hardmetal products and blanks, which are then ground and polished. Soft machining and extrusion are also carried out. It is not known when production of RTP powder started. Ammonium paratungstate (APT) was used as the starting material in the manufacture of tungsten carbide (WC) powder until the 1980s. APT was produced from ore until 1972, after which it was bought in. From the 1980s until 2008 tungsten oxides were the starting material and since 2008 tungsten carbide has been the starting point. Less information was available about the manufacture of solid metal products. At the start of the 1970s the RTP plant was smaller. Today, the processes are the same with the exception of spray drying which was introduced in 1975 . The facility for the manufacture of solid metal products was built in the late 1970s/1980. It is likely that prior to this these products were produced in the same Plant as RTP. Automation started at the end of the 1970s/start of the 1980s and was gradual. The rate of automation increased in the 1990s and now most processes are automatic. The number of workers has decreased as automation has increased. Currently there are approximately 210 workers on Plant.

For Factory B, production of hardmetal products and inserts from imported RTP powder started in 1966. Production increased during the 1970s and into the 1980s. In 2014 it produced cemented carbide cutting tools and tools systems for the metalworking industry. At the time of closure (November 2014) there were approximately 140 workers on Plant. The process area was divided into 3 areas: pre-sintering, which included a press shop and soft machining; sintering; and postsintering, which included grinding and surface treatment. 


\section{Occupational Hygiene and Job History Data}

Full details of the occupational hygiene assessment are set out in a companion paper ${ }^{(7)}$. All available occupational hygiene data were obtained for both factories, either in electronic form or paper form. These were processed and converted to a useable form for exposure assessment before being passed in anonymised form to UIC for the overall exposure assessment. Only personal measurement data were included. A separate exposure assessment for the UK was not carried out due to the small volume of data and the likelihood of the cross-country assessment providing more robust assessment of potential exposures for given jobs. Measurement data were available from 1994 - 2013 for Factory A. In addition, a small amount of data from 1988 were obtained from the UK National Exposure Database (NEDB) for Factory ${ }^{(8)}$. Although not always stated, it appears that the majority of measurements were taken as part of routine measurement programmes. For Factory B measurement data were available from 2002-2013. Measurement data are summarised in Table 2. In addition a history of production at both UK factories was obtained via a structured questionnaire administered to the Environment, Health and Safety (EHS) managers at both factories. Further information about Factory A was collected during a factory visit which included a tour of the factory and interviews with long-serving employees previously identified by the factory managers as useful points of contact for the study. Information collected included details about the raw materials used, process changes, ventilation, work activities and use of personal protective equipment.

No visit to the Factory B was possible due to impending closure of site. Limited information was gathered from a long-serving employee at Factory A who had previously worked at Factory B.

In the overall exposure assessment, job exposure matrices (JEMs) were formed for tungsten, cobalt and nickel, with the JEMs consisting of job dictionary classes and exposure estimates generated using the available exposure data from all of the plants in the international study ${ }^{(7)}$.

\section{Vital Status Tracing and Cause of Death Information}


A reconciled file of human resources data was sent to the NHS Digital, via their secure data upload/download service. Where individuals were identified as having died, date of death and underlying and associated causes of death were provided in coded form according to the revision in force at time of death. Details of individuals who could not be traced or who were regarded as embarked (no longer registered with a general practitioner in England or Wales - usually people who are no longer resident there) were also supplied.

\section{Population and Mortality Data}

Mortality data for England and Wales were assembled from a database already held by the IOM for the disease codes of a priori interest. In addition, mortality and population data for the West Midlands were purchased from the Office for National Statistics.

\section{Case-control Study}

For each lung cancer death a random sample of 6 matched controls were identified, matched on exact age of the case at time of death and then on year of birth and sex. Match on year of birth was within 12 months, but this was relaxed to 24 months in the event of too few candidate controls.

NHS Digital approached proxy respondents for cases on the study team's behalf. These were either informants on the death certificates, or if the informant had also died, it was the informant on the informant's death certificate. Where a proxy respondent for a case was interviewed, a set of matched controls was provided to NHS Digital to approach for inclusion in the study, with the aim of including at least one control per case. Where controls had died, the same procedure for the cases was followed to identify a proxy respondent. Where the control was alive, the patient was written to via their general practitioner (GP). Through this route the research team asked the GP to pass on the study details if they were happy for their patient to participate, or if not to inform the research team of this. GPs were paid $f 10$ to reimburse them for the administration time of passing on the 
information. If no controls responded for a case, an additional 6 controls were identified and provided to NHS Digital to approach for inclusion in the study; this was repeated if required.

For each of the potential case and control respondents or proxy respondents an initial package was sent, including: a cover letter from NHS Digital; letter of invitation from IOM; an information sheet; a consent form; and a pre-paid envelope to send the consent form back to IOM. For those that did not respond within a 2-3 week period a reminder letter was sent.

Each proxy respondent or live control was interviewed by a member of the research team by telephone using a structured interview schedule that was as consistent as possible to that used in the US ${ }^{(9)}$ and Sweden ${ }^{(10)}$ but included more specific changes (e.g. to levels of education/qualifications). Information was collected on additional jobs held outside the hardmetal manufacturing industry and also on lifestyle factors including smoking history. In return for their time taken to participate in the interview (approximately 20-25 minutes), each respondent received a f10 shopping gift card.

\section{Statistical Analysis}

SMRs were calculated, together with their associated $95 \%$ confidence intervals based on the Poisson distribution, for all disease categories with 5 or more deaths using 5-year age and calendar year groups and sex using Genstat ${ }^{(11)}$. All other statistical analyses were carried out using Stata ${ }^{(12)}$. Odds ratio for lung cancer mortality were calculated using conditional logistic regression. 


\section{RESULTS}

\section{Enumerated cohort and vital status tracing}

It was anticipated from the feasibility study, which preceded this study ${ }^{(13)}$, that around 2,000 workers would be identified from the two UK factories. In the event, after 21 exercised their right to opt out of the study following the worker presentations, and duplicates were removed from the file, details for 1,626 workers were submitted to NHS Digital for tracing. After exclusion of 99 workers who could not be traced, many of whom had non-UK addresses, 1,538 workers (94.6\%) were available for inclusion in the cohort study analysis.

\section{Summary Statistics}

Based on the available hygiene data, there is strong evidence that cobalt levels were higher in factory A, and varied over time, with exposures being highest in the late 1990s early 2000s. There was no evidence for a difference in levels between maintenance and other workers. For the tungsten data, exposures were also higher on average at factory A. There was no evidence for a difference in levels between maintenance and non-maintenance workers and exposures were lower post-2000 compared with during the 1980s. For nickel exposures, there was evidence that these were higher at factory $\mathrm{A}$, but there was no evidence of differences between maintenance and other operations or between time periods. There was no evidence for an difference in inhalable dust levels between any of the subgroups examined.

The 1,535 workers included in the study were associated with 34,264 person-years of follow-up from 1980 to 2014 . Around $35 \%$ of the cohort was born before 1950 and some $85 \%$ were male (Table 1 ). The majority of employment information for the cohort came from the hardmetal company's corporate office and for just over half of the workforce, it was not possible to identify clearly whether or not they had worked at factory A or B. Around $5 \%$ of the workforce were employed for less than 12 months and just under $30 \%$ were employed for 20 or more years. Approximately $30 \%$ were aged less than 25 at hire and just over $30 \%$ were aged 35 or over at hire. Around $10 \%$ of the 
cohort were first hired before 1970 and just under 15\% first hired during 1970-1979. For just under $15 \%$ of the cohort, there are more than 40 years of follow-up since first employment. Nearly $25 \%$ of the cohort had insufficient job history data for it to be determined whether they worked in maintenance; of the remainder around $40 \%$ only ever worked in unexposed jobs. Just under $10 \%$ ever worked in maintenance. There were 177 deaths in the cohort during the study follow-up period (1980-2014), with an additional 17 deaths after the end of follow-up (Table 3).

There were 19 lung cancer deaths that all occurred in men. Four occurred in men born in the 1920s, eight in men born in the 1930s, five in men born in the 1940s and two in men born in the 1950s. Nine worked at Factory A, three at Factory B, and the other seven either worked elsewhere or it wasn't known where they worked. Eleven of the lung cancer deaths worked for 5-19 years in the industry and eight for 20 years or more. Three cases had time since first employment of less than 20 years, for three it was 20-29 years, for three it was 30-39 years and for ten cases it was more than 40 years since first employment. Only one case was aged less than 25 at hire, five were aged 25-34 at hire and the remaining 13 were aged 35 or over at hire. Six of the lung cancer deaths worked in maintenance at some point during their time in the industry.

\section{Standardized Mortality Ratios}

Table 4 shows for the UK cohort the SMRs for all causes of death with at least five deaths. As well as England and Wales, deaths rates for the West Midlands region of England were also used for comparison purposes. For all causes of death combined there were statistically significant deficits in mortality, 5\% compared with England and Wales and 34\% compared with the West Midlands. The deficits were significant for males and females. For all malignant neoplasms there was a nonsignificant deficit of 7\% compared with England and Wales and 9\% compared with the West Midlands. The deficit was $47 \%$ for women but the number of cancer deaths was as expected for men. All deaths from malignant neoplasms of the respiratory system occurred in men. The deficit compared with England and Wales rates was $9 \%$ and compared with the West Midlands was $9 \%$ 
(men and women combined). For malignant neoplasms of the trachea, bronchus and lung the SMR for England and Wales rates showed a deficit of $15 \%$ and the same based on West Midlands rates (male and female combined).

The SMR for lung cancer at factory A was 140 (95\% confidence interval (CI): 73 to 269, based on 9 cases), at factory B was 160 (55 to 524,3 ) and where site was neither factory A or B or was unknown was $62(29$ to 130,7$)$. Examining the SMRs by length of employment gave SMRs of 172 (95 to 311, 11) for workers employer 5-19 years and $91(45$ to 192, 8) for workers employed for 20 years or more. For ever worked in maintenance, the SMR was 231 (104 to 514, 6) which was statistically significantly raised, albeit based on only six cases. For never involved in the maintenance the SMR was $96(56$ to 165,13$)$.

For the major non-malignant causes of death, the SMR for men showed a 19\% deficit for cerebrovascular disease (England and Wales) and there were only three deaths in women. For ischaemic heart disease, the deficit in men was more marked (32\%) and statistically significant, and there was only a single death among women. For non-malignant respiratory diseases there was also a statistically significant deficit in men of $52 \%$ and only a single death in women.

\section{Case-control Study}

Only 15 of the 19 cases were available for the case-control study, due to one case having been registered by a coroner and the other by a hospital official, and two not being picked up by the study team until late in the recruitment process. Only six of the remaining 15 responded to our invitation for the case-control study and agreed to take part, thus limiting our ability to explore exposure associations with lung cancer.

The odds ratios for lung cancer for ever worked with hardmetal, tungsten or cobalt could not be calculated due to all cases having been exposed or the proxy respondent did not know whether the case was exposed. Only two cases and three controls reported a length of exposure to hardmetal in 
years. Only two cases and four controls reported a length of exposure to tungsten in years and one case and three controls reported a length of exposure to cobalt in years. The odds ratio for years of exposure to hardmetal, tungsten carbide and cobalt were 0.93 (0.76 to 1.13 ), 0.93 (0.77 to 1.12 ) and 0.94 (0.78 to 1.13) respectively, suggesting lengths of exposure were longer on average for controls than for cases. As nine of the 10 cases smoked, adjustment for ever or never smoked did not affect the findings, although they are based on very small numbers. A sensitivity analysis using duration of employment, based on cohort data, and so without missing data, yielded a very similar odds ratio with a slightly narrower $95 \%$ confidence interval of 0.94 (0.82 to 1.08$)$. 


\section{DISCUSSION}

\section{Epidemiological studies in the industry}

In a cohort study of 3,163 men employed for at least one year in one of three Swedish hardmetal production facilities, followed-up from 1951 to 1982, the standardized mortality ratio (SMR) for for lung cancer was $134(77 \text { to } 213,17)^{(2)}$. In a cohort study of 709 men employed for at least one year between 1956 and 1989 in a hardmetal production factory in the centre of France, the SMR for lung cancer was marginally statistically significantly raised at $213(102 \text { to } 393,10)^{(3)}$. A case-control study of lung cancer mortality nested within a cohort of workers ever employed at one of 10 hardmetal facilities in France (Plant 4 of which was studied in the earlier analysis) was followed-up from 1968 to 1991 . For men and women combined the SMR for lung cancer was $130(100 \text { to } 166,63)^{(4)}$. In the case-control study, match on age and date of birth and adjusted for other potential carcinogens, employment in a maintenance workshop, socioeconomic level and smoking, when exposures recorded during the last 10 years were ignored the odds ratio was 1.93 (1.03 to 3.62) for workers simultaneously exposed to cobalt and tungsten carbide and 2.21 (0.99 to 4.90) adjusted for other cobalt exposure. There was evidence that the risk increased with cumulative exposure and to a lesser extent with duration of exposure and this was robust to adjustment for smoking and exposure to other occupational carcinogens ${ }^{(4)}$. A cohort mortality study of 3,398 subjects who were employed for at least 3 months during 1950 to 1992 was carried out at a French hardmetal manufacturing facility in France with follow-up from 1969 to 1992. For mortality from all causes in men the SMR for lung cancer was $170(124$ to 226,46$)$ and there was only a single death among women. There was evidence, from analyses using Poisson regression, for a significant increase in risk with duration of employment to hardmetal dust before sintering after adjustment for smoking and known or suspected carcinogens (5). This study had been included in the earlier French study of multiple sites and was probably studied in more detail due to the previous excess of lung cancer mortality. The International Agency for Research on Cancer (IARC) working group subsequently concluded that cobalt metal with tungsten carbide is probably carcinogenic in humans, Group $2 \mathrm{~A}^{(14)}$. 
Cobalt with tungsten carbide was identified as a priority for a discussion about future research priorities by an IARC/National Occupational Research Agenda collaboration project ${ }^{(6)}$.

\section{Findings from this study}

This small cohort exhibited overall deficits in mortality that are consistent with the so called "healthy worker effect" (15). This effect usually arises out of a selection effect of healthy individuals at the commencement of employment, and often disappears as follow-up of a cohort is extended. This cohort is young with only 169 out of $1,535(11.0 \%)$ of the study population having died by the end of follow-up. The use of local rates, in additional to national rates did not produce SMRs that were materially different from each other, reflecting that mortality risks in the West Midlands were similar to that for England and Wales. There were relatively few short-term workers, just over 5\%, and so their recognised adverse mortality outcomes ${ }^{(16)}$ would not have impacted greatly on the results of this study.

Lung cancer was the outcome of strongest of a priori interest, given the IARC classification of Group $2 \mathrm{~A}$, probably carcinogenic, based on risk of lung cancer ${ }^{(14)}$. Looking at subgroups for lung cancer, the SMR for maintenance workers was elevated, but based on only six deaths. Three of the lung cancer cases had durations of employment and time since first exposure of less than 10 years. Thus examination if duration of employment and time since first exposure did not provide strong evidence against work in the industry being carcinogenic.

The findings from the nested case-control study of lung cancer were consistent with the lung cancer SMR from the cohort analysis, although based on very small numbers ${ }^{(17,18)}$.

There were unfortunately many gaps in the historic employment data for individuals, particularly before the early 2000s when the company's current human resources database was established. We anticipate that many early workers employed at both Factory A and Factory B would not have been 
included in this cohort, because the records were not retained by the company. We cannot rule out therefore a healthy worker survivor effect operating in the cohort ${ }^{(19)}$.

The proportion of workers untraced was slightly higher than the minimum expected ( $5.4 \%$ compared with the expectation of $<5 \%$ ), due in part to a non-trivial number of non-UK nationals who were not registered with a UK GP and therefore not present on the National Health Service Central Register.

The findings from this study in relation to lung cancer were inconsistent with the body of evidence examined from the Swedish and French studies previously considered by IARC ${ }^{(14)}$. The IARC working group stopped short of suggesting the evidence of carcinogenicity for exposure to cobalt with a tungsten carbide binder was sufficient because of the lack of adjustment for tobacco smoking, gaps in work history data, and most importantly a lack of quantitative exposure data on which to reliably model exposure-response ${ }^{(14)}$. These findings are not inconsistent with more recent reviews of the epidemiological evidence ${ }^{(20,21)}$.

This study on its own lacked statistical power to detect anything other than large relative risks of lung cancer. The studies that have been carried out in the US ${ }^{(9)}$, Sweden ${ }^{(10)}$, Germany ${ }^{(22)}$ and Austria ${ }^{(23)}$, separately and, particularly, the inclusion of this study as part of a pooled analysis of data from all the countries ${ }^{(24)}$ provide more definitive information on cancer mortality risk in the hardmetal manufacturing industry. 


\section{CONCLUSIONS}

Our findings from this small study of workers in the UK hardmetal manufacturing industry provided no support for the contention that employment within the industry increases the risk of death from lung cancer or any other cause of death. The international pooled analysis provides firmer conclusions about mortality risk in the industry. 


\section{ACKNOWLEDGEMENTS}

The design, conduct, analysis and conclusions of the study are exclusively those of the authors. We would like to acknowledge the cooperation and assistance of the representatives from the ITIA and its member companies. In particular, we thank all the employees that provided assistance throughout the study.

We additionally would like to thank Marlyn Davis and James Osbourne for administrative support. 


\section{REFERENCES}

1. Santhanam AT. Kirk-Othmer Encyclopedia of Chemical Technology. In: Kroschwitz JJ, HoweGrant M, eds. Cemented Carbides. New York: John Wiley \& Sons; 1992:848-860.

2. Hogstedt C, Alexandersson R. Mortality among hardmetal workers. Arbete Hälsa. 1990;21:126.

3. Lasfargues G, Wild P, Moulin JJ, et al. Lung cancer mortality in a french cohort of hard-metal workers. American Journal of Industrial Medicine. 1994;26:585-595.

4. Moulin JJ, Wild P, Romazini S, et al. Lung Cancer Risk in Hard-Metal Workers. American Journal of Epidemiology. 1998;148:241-248.

5. Wild P, Perdrix A, Romazini S, Moulin J-J, Pellet F. Lung cancer mortality in a site producing hard metals. Occupational and Environmental Medicine. 2000;57:568-573.

6. Ward EM, Schulte PA, Straif K, et al. Research Recommendations for Selected IARC-Classified Agents. Environmental Health Perspectives. 2010;118:1355-1362.

7. Marsh G, Buchanich J, Zimmerman S, et al. Mortality among Hardmetal Production Workers: US Cohort and Nested Case-Control S. Journal of Occupational and Environmental Medicine. 2017tudies;Submitted.

8. Burns DK, Beaumont PL. The HSE National Exposure Database - (NEDB). Annals of Occupational Hygiene. 1989;33:1-14.

9. Marsh GM, Buchanich JM, Zimmerman S, et al. Mortality among Hard Metal Production Workers: US Cohort and Nested Case-Control Studies. Journal of Occupational and Environmental Medicine. 2017; Submitted.

10. Westberg H, Bryngelsson I, Marsh G, et al. Mortality in the Swedish hardmetal industry exposure to cobalt, nickel and tungsten carbide. Journal of Occupational and Environmental Medicine. 2017; Submitted.

11. Payne RW, Murray DA, Harding SA, Baird DB, Soutar DM. Genstat for Windows (12th Edition). Introduction. Hemel Hemstead: VSN International; 2009.

12. StataCorp. Stata Statistical Software: Release 13. College Station, TX: StataCorp LP; 2013. 13. Marsh GM, Buchanich JM, Zimmerman S. ITIA Tungsten Carbide Study Final Phase 2 Report and Phase 3 Protocol (Report, 11-07-08). University of Pittsburgh; 2008.

14. IARC. Cobalt in Hard Metals and Cobalt Sulfate, Gallium Arsenide, Indium Phosphide and Vanadium Pentoxide. Lyon: IARC; 2006.

15. Li C-Y, Sung F-C. A review of the healthy worker effect in occupational epidemiology. Occupational Medicine. 1999;49:225-229.

16. Kolstad HA, Olsen J. Why Do Short Term Workers Have High Mortality? American Journal of Epidemiology. 1999;149:347-352.

17. Behl M, Stout MD, Herbert RA, et al. Comparative toxicity and carcinogenicity of soluble and insoluble cobalt compounds. Toxicology. 2015;333:195-205.

18. National Toxicology Program. Monograph on cobalt and cobalt compounds that release cobalt ions in vivo. Report on Carcinogens: US Department of Health and Human Services; 2016. 19. Arrighi HM, Hertz-Picciotto I. The Evolving Concept of the Healthy Worker Survivor Effect. Epidemiology. 1994;5:189-196.

20. Wild P, Bourgkard E, Paris C. Lung Cancer and Exposure to Metals: The Epidemiological Evidence. In: Verma M, ed. Cancer Epidemiology: Modifiable Factors. Totowa, NJ: Humana Press; 2009:139-167.

21. National Toxicology Program. Report on Carcinogens: Monograph on Cobalt and Cobalt Compounds that Release Cobalt lons In Vivo. US Department of Health and Human Services; 2016.

22. Morfeld P, Groß JV, Erren TC, et al. Mortality among Hard Metal Production Workers: German Historical Cohort Study. Journal of Occupational and Environmental Medicine. 2017; Submitted. 
23. Wallner $\mathrm{P}$, Kundi $\mathrm{M}$, Moshammer $\mathrm{H}$. A retrospective cohort study in the Austrian hard metal industry. Journal of Occupational and Environmental Medicine. 2017;Submitted.

24. Marsh G, Buchanich J, Zimmerman S, et al. Mortality among Hardmetal Production Workers: Pooled Analysis of Cohort Data from an International Investigation. Journal of Occupational and Environmental Medicine. 2017;Submitted. 


\section{APPENDIX - STUDY CLEARANCES}

The equivalent of Institution Review Board approval for the study was obtained from the School of Life Sciences Ethics Committee of Heriot-Watt University. Ethical clearance for the study was obtained from the Black Country National Health Service Ethics Committee (Ref: 13/WM/0006), initially for the cohort study and via a substantial amendment for the nested case-control study with a second substantial amendment for the nested case-control study for additional reminder forms for proxies for cases, controls and proxies for controls. The Health Research Authority Confidentiality Advisory Group gave permission for the study to go ahead without obtaining individual informed consent from each participant in the cohort study. Appropriate staff with access to identifiable mortality data obtained Approved Researcher Status from the Office for National Statistics (DMM, LAM, and CA). Approval to receive mortality data from the National Health Service (NHS) was obtained from NHS Digital's Data Access Advisory Group. Presentations were given to current workers and a worker leaflet containing an opt-out form prepared, both of which gave workers the opportunity to opt out without giving a reason and also the opportunity to withdraw from the study at any stage also without having to give a reason. This leaflet was also sent to current members of the company pension scheme. Finally, a Data Sharing Agreement was signed between the Institute of Occupational Medicine (IOM) and the hardmetal company to facilitate the provision of human resources and related data to the IOM study team for the purposes of epidemiological research. 
Table 1: Description of study participants

\section{Characteristics Number (Percentage)}

\begin{tabular}{|c|c|}
\hline Year of birth: & \\
\hline Before 1920 & $13(0.8)$ \\
\hline 1920-1929 & $81(5.3)$ \\
\hline 1930-1939 & $162(10.5)$ \\
\hline 1940-1949 & $277(18.0)$ \\
\hline 1950-1959 & $324(21.1)$ \\
\hline 1960-1969 & 337 (21.9) \\
\hline 1970-1979 & $228(14.8)$ \\
\hline After 1980 & $116(7.5)$ \\
\hline Sex: & \\
\hline Male & $1289(83.8)$ \\
\hline Female & $249(16.2)$ \\
\hline Ever Worked at Factory: & \\
\hline A & $568(36.9)$ \\
\hline B & 155 (10.1) \\
\hline$A$ and $B$ & $5(0.3)$ \\
\hline Not known/neither & $810(52.7)$ \\
\hline Length of employment (years): & \\
\hline $\begin{array}{l}<1 \text { year } \\
1-4\end{array}$ & $\begin{array}{c}98(6.4) \\
260(16.9)\end{array}$ \\
\hline $5-19$ & $630(41.0)$ \\
\hline $20+$ & $426(27.7)$ \\
\hline Not known & $124(8.1)$ \\
\hline Age at Hire: & \\
\hline$<25$ & $436(28.4)$ \\
\hline $25-34$ & $459(29.8)$ \\
\hline $35+$ & $519(33.8)$ \\
\hline Not known & $124(8.1)$ \\
\hline Year of hire: & \\
\hline$<1970$ & $136(8.8)$ \\
\hline $1970-79$ & $227(14.8)$ \\
\hline $1980-89$ & $394(25.6)$ \\
\hline $1990-00$ & $227(14.8)$ \\
\hline $2000+$ & $430(28.0)$ \\
\hline Not known & $124(8.1)$ \\
\hline $\begin{array}{l}\text { Time since first employment } \\
\text { (years): }\end{array}$ & \\
\hline$<20$ & 579 (37.7) \\
\hline $20-29$ & $308(20.0)$ \\
\hline $30-39$ & $293(19.1)$ \\
\hline $40+$ & $234(15.2)$ \\
\hline Not known & $124(8.1)$ \\
\hline Ever Worked in Maintenance & $145(9.4)$ \\
\hline Never Worked in Maintenance & $396(25.8)$ \\
\hline Unexposed & $617(40.1)$ \\
\hline Not known & $380(24.7)$ \\
\hline
\end{tabular}




\begin{tabular}{|l|c|}
\hline Vital Status: & $1,315(80.9)$ \\
Alive & $194(11.9)$ \\
Dead & \\
Not resident in England or & $29(1.8)$ \\
Wales & $88(5.4)$ \\
Untraced & \\
\hline
\end{tabular}


Table 2: Summaries of Exposure Measurements for Cobalt, Tungsten, Nickel and Total Inhalable Dust for the UK Plants $\left(\mathrm{mg} / \mathrm{m}^{3}\right)$

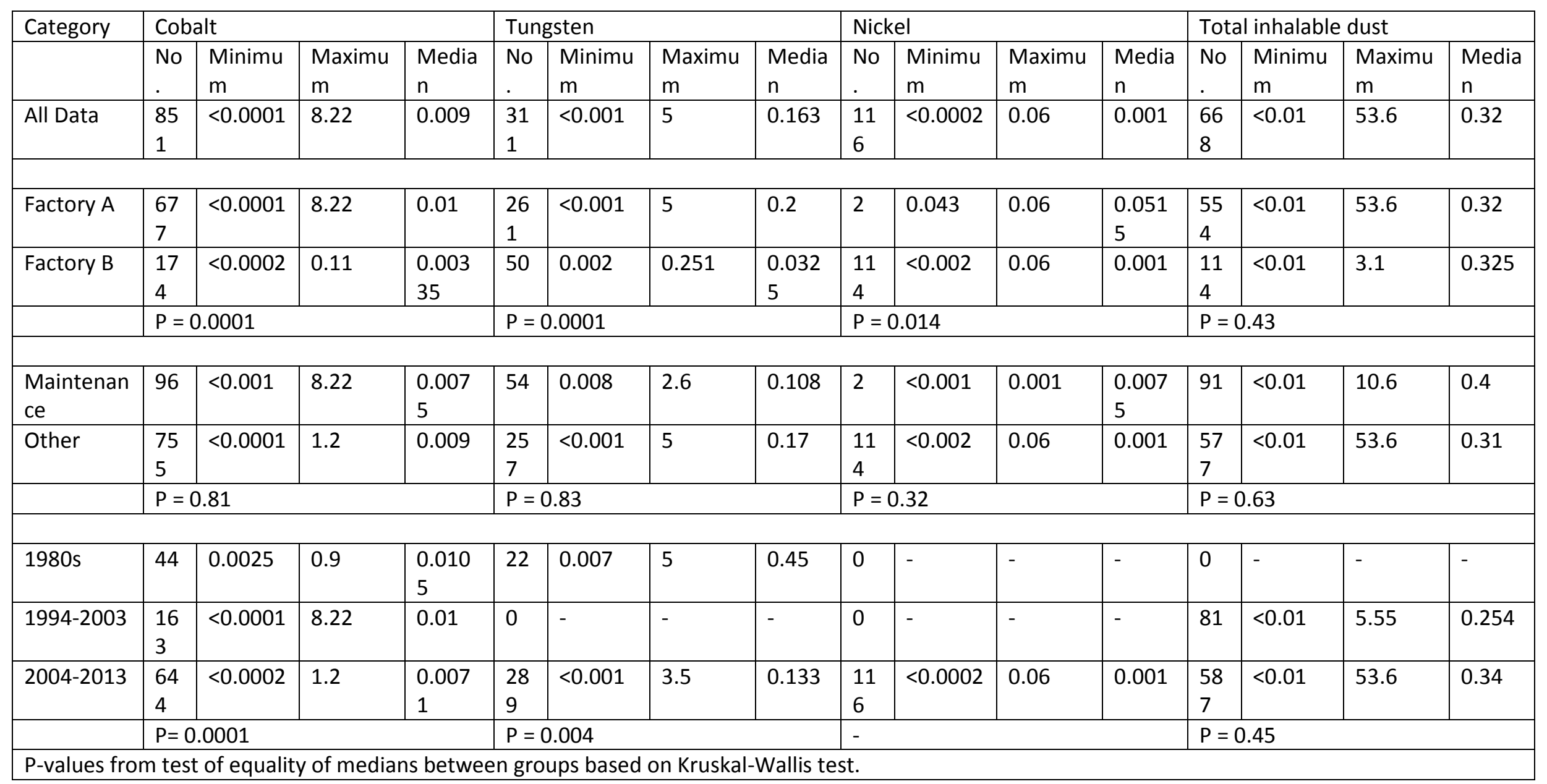


Table 3: Distribution of deaths

\begin{tabular}{|c|c|c|c|}
\hline $\begin{array}{l}\text { Cause of Death } \\
\text { (ICD9; ICD10) }\end{array}$ & $\begin{array}{c}\text { Frequency } \\
\text { ICD9 during follow-up }\end{array}$ & $\begin{array}{c}\text { Frequency } \\
\text { ICD10 during follow-up }\end{array}$ & $\begin{array}{c}\text { Frequency } \\
\text { ICD10 after end of follow-up }\end{array}$ \\
\hline Infectious diseases (001-139; A00-B99) & 0 & 1 & 0 \\
\hline MN digestive system (150-159; C15-C26) & 10 & 14 & 0 \\
\hline MN respiratory system $(160-165 ;$ C30-C39) & 6 & 13 & 0 \\
\hline $\begin{array}{l}\text { MN bone, connective tissue and breast (170-175; } \\
\text { C40-C50) }\end{array}$ & 3 & 2 & 1 \\
\hline MN genitourinary organs (179-189; C51-C68) & 5 & 8 & 2 \\
\hline MN other \& unspecified sites (190-199; C69-C80) & 2 & 7 & 0 \\
\hline $\begin{array}{l}\text { MN lymphatic \& haematopoietic tissue (200-208; } \\
\text { C81-C96) }\end{array}$ & 1 & 9 & 0 \\
\hline $\begin{array}{l}\text { Benign \& uncertain behaviour neoplasms (210- } \\
\text { 229; D10-D48) }\end{array}$ & 0 & 0 & 1 \\
\hline $\begin{array}{l}\text { Disease of other endocrine glands (249-259; E20- } \\
\text { E35) }\end{array}$ & 1 & 0 & 0 \\
\hline $\begin{array}{l}\text { Mental and behavioural disorders (290-319; F00- } \\
\text { F99) }\end{array}$ & 2 & 2 & 2 \\
\hline Nervous system diseases (320-359; G00-G99) & 1 & 0 & 1 \\
\hline Circulatory system diseases (390-459; 100-199) & 25 & 35 & 5 \\
\hline Respiratory system diseases (460-519; J00-J99) & 3 & 9 & 1 \\
\hline Digestive system diseases (520-579; K00-K93) & 0 & 8 & 2 \\
\hline $\begin{array}{l}\text { Genitourinary system diseases (580-629; N00- } \\
\text { N98) }\end{array}$ & 0 & 0 & 1 \\
\hline $\begin{array}{l}\text { Symptoms, signs \& ill-defined conditions (780- } \\
\text { 799; R00-R99) }\end{array}$ & 1 & 3 & 0 \\
\hline $\begin{array}{l}\text { Injury \& poisoning \& other external causes (800- } \\
\text { 999; S00-Y98) }\end{array}$ & 1 & 5 & 1 \\
\hline Total & 61 & 116 & 17 \\
\hline
\end{tabular}


Table 4: SMRs, National (England and Wales, 1980-2014) and Local (West Midlands, 1980-2014)

\begin{tabular}{|c|c|c|c|c|c|c|c|c|c|c|c|c|}
\hline \multirow{3}{*}{$\begin{array}{l}\text { Cause of death (ICD } \\
9 ; 10 \text { codes) }\end{array}$} & \multicolumn{9}{|c|}{ England and Wales } & \multirow{2}{*}{\multicolumn{3}{|c|}{$\begin{array}{c}\text { West Midlands } \\
\text { Total }\end{array}$}} \\
\hline & \multicolumn{3}{|c|}{ Males } & \multicolumn{3}{|c|}{ Females } & \multicolumn{3}{|c|}{ Total } & & & \\
\hline & $\begin{array}{c}\text { No. } \\
\text { deaths } \\
\text { (0) }\end{array}$ & SMR & $95 \% \mathrm{Cl}$ & $\begin{array}{c}\text { No. } \\
\text { death } \\
\text { s (O) }\end{array}$ & SMR & $95 \% \mathrm{Cl}$ & $\begin{array}{l}\text { No. } \\
\text { deaths } \\
\text { (O) }\end{array}$ & SMR & $95 \% \mathrm{Cl}$ & $\begin{array}{c}\text { No. } \\
\text { deaths } \\
\text { (O) }\end{array}$ & SMR & $95 \% \mathrm{Cl}$ \\
\hline $\begin{array}{l}\text { All causes of death } \\
\text { (001-999; A00-Y89 }\end{array}$ & 161 & 72 & 62 to 84 & 16 & 43 & 27 to 71 & 177 & 68 & 59 to 79 & 177 & 66 & 57 to 7 \\
\hline $\begin{array}{l}\text { All malignant } \\
\text { neoplasms (140-208; } \\
\text { C00-C97) }\end{array}$ & 73 & 100 & 79 to 126 & 7 & 53 & 25 to 110 & 80 & 93 & 74 to 115 & 80 & 91 & 73 to 133 \\
\hline $\begin{array}{l}\text { MN digestive organs } \\
\text { and peritoneum } \\
(150-159 ; \mathrm{C} 15- \\
\mathrm{C} 26, \mathrm{C} 48)\end{array}$ & 19 & 92 & 59 to 144 & 2 & - & - & 24 & 94 & 53 to 141 & 24 & 89 & 60 to 133 \\
\hline $\begin{array}{l}\text { MN respiratory } \\
\text { system (160-165; } \\
\text { C30-C39) }\end{array}$ & 19 & 92 & 59 to 144 & 0 & - & - & 19 & 81 & 52 to 127 & 19 & 81 & 51 to 126 \\
\hline $\begin{array}{l}\text { MN trachea, } \\
\text { bronchus and lung } \\
(162 ; \text { C33-C34) }\end{array}$ & 19 & 97 & 69 to 152 & 0 & - & - & 19 & 85 & 54 to 134 & 19 & 85 & 54 to 133 \\
\hline $\begin{array}{l}\text { MN all male genital } \\
\text { organs (185-189, } \\
\text { C660-C63) }\end{array}$ & 8 & 121 & 61 to 242 & - & - & - & 8 & 121 & 61 to 242 & 8 & 122 & 61 to 243 \\
\hline $\begin{array}{l}\text { MN prostate (185; } \\
\text { C61) }\end{array}$ & 8 & 126 & 63 to 251 & - & - & - & 8 & 126 & 63 to 251 & 8 & 126 & 63 to 253 \\
\hline $\begin{array}{l}\text { MN all lymphatic and } \\
\text { haematopoietic } \\
\text { tissue (200-208; C81- } \\
\text { C96) }\end{array}$ & 10 & 168 & 90 to 312 & 0 & - & - & 10 & 145 & 78 to 269 & 10 & 145 & 78 to 269 \\
\hline $\begin{array}{l}\text { Cerebrovascular } \\
\text { disease (330-334, }\end{array}$ & 11 & 81 & 45 to 147 & 3 & - & - & 14 & 85 & 50 to 143 & 14 & 79 & 47 to 133 \\
\hline
\end{tabular}




\begin{tabular}{|c|c|c|c|c|c|c|c|c|c|c|c|c|}
\hline \multirow{3}{*}{$\begin{array}{l}\text { Cause of death (ICD } \\
9 ; 10 \text { codes) }\end{array}$} & \multicolumn{9}{|c|}{ England and Wales } & \multirow{2}{*}{\multicolumn{3}{|c|}{$\begin{array}{c}\text { West Midlands } \\
\text { Total }\end{array}$}} \\
\hline & \multicolumn{3}{|c|}{ Males } & \multicolumn{3}{|c|}{ Females } & \multicolumn{3}{|c|}{ Total } & & & \\
\hline & $\begin{array}{c}\text { No. } \\
\text { deaths } \\
\text { (0) }\end{array}$ & SMR & $95 \% \mathrm{Cl}$ & $\begin{array}{l}\text { No. } \\
\text { death } \\
\text { s (0) }\end{array}$ & SMR & $95 \% \mathrm{Cl}$ & $\begin{array}{c}\text { No. } \\
\text { deaths } \\
\text { (O) }\end{array}$ & SMR & $95 \% \mathrm{Cl}$ & $\begin{array}{c}\text { No. } \\
\text { deaths } \\
\text { (0) }\end{array}$ & SMR & $95 \% \mathrm{Cl}$ \\
\hline $\begin{array}{l}\text { 430-438, 430-438, } \\
160-169)\end{array}$ & & & & & & & & & & & & \\
\hline $\begin{array}{l}\text { Ischaemic heart } \\
\text { disease (420 422.1, } \\
410-414,410-414, \\
\text { I20-I25) }\end{array}$ & 35 & 68 & 49 to 94 & 1 & - & - & 36 & 64 & 46 to 88 & 36 & 61 & 44 to 85 \\
\hline $\begin{array}{l}\text { Non-malignant } \\
\text { respiratory disease } \\
(460-519 ; 100-199)\end{array}$ & 11 & 48 & 27 to 86 & 1 & - & - & 12 & 44 & 25 to 77 & 12 & 43 & 24 to 75 \\
\hline $\begin{array}{l}\text { Influenza and } \\
\text { pneumonia (480- } \\
487 ; \text { J10-J18) }\end{array}$ & 6 & 80 & 36 to 177 & 0 & - & - & 6 & 67 & 30 to 148 & 6 & 69 & 31 to 154 \\
\hline
\end{tabular}


Clinical Significance

\section{Statement of Clinical Significance}

This retrospective cohort study of workers in the UK hardmetal industry provides no support for the hypothesis that work in the industry increases mortality from any cause, including lung cancer. 